\title{
Loricate choanoflagellates (Acanthoecida) from warm water seas. VII. Calotheca Thomsen and Moestrup, Stephanacantha Thomsen and Syndetophyllum Thomsen and Moestrup
}

Thomsen, Helge Abildhauge; Kamennaya, Nina; Zubkov, Mikhail V.; Østergaard, Jette Buch

Published in:

European Journal of Protistology

Link to article, DOI:

10.1016/j.ejop.2020.125728

Publication date:

2020

Document Version

Peer reviewed version

Link back to DTU Orbit

Citation (APA):

Thomsen, H. A., Kamennaya, N., Zubkov, M. V., \& Østergaard, J. B. (2020). Loricate choanoflagellates (Acanthoecida) from warm water seas. VII. Calotheca Thomsen and Moestrup, Stephanacantha Thomsen and Syndetophyllum Thomsen and Moestrup. European Journal of Protistology, 76, [125728]. https://doi.org/10.1016/j.ejop.2020.125728

\section{General rights}

Copyright and moral rights for the publications made accessible in the public portal are retained by the authors and/or other copyright owners and it is a condition of accessing publications that users recognise and abide by the legal requirements associated with these rights.

- Users may download and print one copy of any publication from the public portal for the purpose of private study or research.

- You may not further distribute the material or use it for any profit-making activity or commercial gain

- You may freely distribute the URL identifying the publication in the public portal 


\section{Journal Pre-proof}

Loricate choanoflagellates (Acanthoecida) from warm water seas. VII. Calotheca Thomsen and Moestrup, Stephanacantha Thomsen and Syndetophyllum Thomsen and Moestrup

Helge Abildhauge Thomsen, Nina A. Kamennaya, Mikhail V.

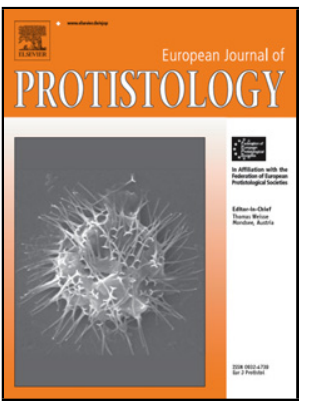

Zubkov, Jette Buch Østergaard

\begin{tabular}{|c|c|}
\hline PII: & S0932-4739(20)30058-4 \\
\hline DOI: & https://doi.org/10.1016/j.ejop.2020.125728 \\
\hline Reference: & EJOP 125728 \\
\hline To appear in: & European Journal of Protistology \\
\hline Received Date: & 6 May 2020 \\
\hline Revised Date: & 17 June 2020 \\
\hline ccepted Date: & 25 June 2020 \\
\hline
\end{tabular}

Please cite this article as: Thomsen HA, Kamennaya NA, Zubkov MV, Østergaard JB, Loricate choanoflagellates (Acanthoecida) from warm water seas. VII. Calotheca Thomsen and Moestrup, Stephanacantha Thomsen and Syndetophyllum Thomsen and Moestrup, European Journal of Protistology (2020), doi: https://doi.org/10.1016/j.ejop.2020.125728

This is a PDF file of an article that has undergone enhancements after acceptance, such as the addition of a cover page and metadata, and formatting for readability, but it is not yet the definitive version of record. This version will undergo additional copyediting, typesetting and review before it is published in its final form, but we are providing this version to give early visibility of the article. Please note that, during the production process, errors may be discovered which could affect the content, and all legal disclaimers that apply to the journal pertain.

(C) 2020 Published by Elsevier. 
Loricate choanoflagellates (Acanthoecida) from warm water seas. VII. Calotheca Thomsen and Moestrup, Stephanacantha Thomsen and Syndetophyllum Thomsen and Moestrup.

Helge Abildhauge Thomsen ${ }^{a,}{ }^{,}$, Nina A. Kamennaya ${ }^{b, 1}$, Mikhail V. Zubkov ${ }^{b, 2}$ and Jette Buch $\emptyset_{\text {stergaard }}{ }^{\mathrm{C}}$

aTechnical University of Denmark, National Institute of Aquatic Resources (DTU Aqua), Kemitorvet, Bygning 201, DK 2800 Kgs. Lyngby, Denmark / hat@aqua.dtu.dk

${ }^{b}$ National Oceanography Centre, Southampton SO14 3ZH, United Kingdom

'Nørrebrogade 52a 5th, 2200 Copenhagen N, Denmark

*Corresponding author: E-mail address: hat@aqua.dtu.dk (H.A. Thomsen)

Present address: ${ }^{1}$ French Associates Institute for Agriculture and Biotechnology of Drylands, BenGurion University of the Negev, Sede-Boqer 849900, Israel

${ }^{2}$ The Scottish Association for Marine Sciences, Scottish Marine Institute, Oban, Argyll, PA37 1QA, United Kingdom

Abstract

The tectiform loricate choanoflagellate genera Calotheca, Stephanacantha and Syndetophyllum have all been first described from warm water habitats and share the presence of flattened and often elaborate costal strips in the lorica. The current reinvestigation does confirm both the widespread occurrence of these taxa within the global warm water belt, and largely corroborates the established genus and species matrix. We describe here Stephanacantha oceanica sp. nov. which closely resembles S. campaniformis, and transfer Parvicorbicula zigzag to the genus Stephanacantha, despite differences in costal strip morphology, but based on a complete agreement in lorica constructional details.

Keywords: Loricate choanoflagellates; Acanthoecida; Ultrastructure; Taxonomy; Biogeography; Warm water seas 


\section{Introduction}

In an ongoing effort (Thomsen and $\varnothing$ stergaard 2019a-e; Thomsen et al. 2020) to provide a first comprehensive overview of warm water loricate choanoflagellate diversity, based on a traditional microscopical approach, we here deal with species of Calotheca Thomsen and Moestrup, 1983, Stephanacantha Thomsen in Thomsen and Boonruang, 1983, and Syndetophyllum Thomsen and Moestrup, 1983. A shared feature of these genera are the flattened costal strips that may have elaborate patterns on laminas extending from the costal strip midrib, conspicuous unilateral spines on anterior transverse costal strips, or a heavy mineralization of the costal strip midrib creating massive 3D-structures.

While the majority of warm water loricate choanoflagellate species possess a lorica constructed from fairly standard rod-shaped costal strips, there is nevertheless, when compared with cold water habitats, a statistically significant overrepresentation in warm water oceanic realms of forms with flattened costal strips. These include in addition to genera mentioned above also e.g. Thomsenella spp. (Thomsen and Østergaard 2019e).

Observations presented below basically confirms the species matrix that was established decades ago (Thomsen and Boonruang 1983; Thomsen and Moestrup 1983) yet adds the description of Stephanacantha oceanica sp. nov., new biogeographical ranges and critical supplementary information on lorica features of some species.

\section{Material and Methods}

The material that constitutes the background for this and a series of papers on warm water acanthoecid choanoflagellates was collected over a period of 35 years. The geographic origin of 
samples is recorded in Fig. 1. See Thomsen and $\emptyset$ stergaard (2019a) for information on each of the collection sites and sampling campaigns.

The general protocol for processing water samples for the light microscope (LM) and transmission electron microscope (TEM) was according to Moestrup and Thomsen (1980) and Thomsen (1982). For details on sample processing, preparational issues and microscopes used see Thomsen and $\varnothing$ stergaard (2019a).

SEM micrographs (Fig. 4a-h) of specimens from the South Pacific (Fig. 1) originate from Au/Pdcoated polycarbonate filters with flow-sorted cells prepared as described by Kamennaya et al. (2018) and imaged with the high-resolution SEM UltraPlus instrument (Zeiss Gemini) at the Imaging and Analysis Centre of the Natural History Museum in London, UK.

The material examined here is dried, which means that the natural 3-D structures have collapsed to become 2-D structures leading to e.g. an artefactual expansion of in particular the lorica width. While several structures can still be measured with confidence, e.g. lorica height and the length of spines and pedicels, it does imply that certain values such as lorica diameter, typically at the level of the transverse costa(e), cannot be measured directly but only calculated from measurements of the circumference. This approach has been taken in the species descriptions below.

Efforts are made to make use of a concise terminology when describing lorica features and we follow the standards that have developed in the course of dealing with these organisms; see e.g. Leadbeater (2015; loc. cit. chapter 4 and glossary p. 278) and Thomsen and Buck (1991).

Before proceeding with the description of genera and species it is necessary to elaborate on an issue of terminology that has major impact on the actual phrasing of the morphological analyses provided below. The mid-lorica zig-zag belt of costal strips observed in species of Stephanacantha 
(e.g. Fig. 5j-I) superficially appears to be an integrated part of the outer layer longitudinal costal system. However, there are two facts that contradicts this interpretation. Components of the zigzag belt are evidently exocytosed and stored first in the costal strip developmental cycle (Fig. 3b, $4 \mathrm{~g}, 6 \mathrm{a})$, which indicates that they do form a separate (inner) layer in parallel with what applies to genuine transverse costal elements (Leadbeater 2015). The fact that both anterior and posterior longitudinal strips (rather than just the posterior strip) overlay costal strips from the zig-zag belt is further evidence that these are not bona fide parts of the outer longitudinal costal strip layer Leadbeater 2015).

The Stephanacantha mid-lorica costal strip zig-zag arrangement is, however, strictly speaking also not a transverse costa as currently circumscribed. Leadbeater (2015) thus defines a transverse costa as being an entire horizontal ring of costal strips that interact precisely with longitudinal costae with which they have clearly definable junctions. It is adequate for the time being to interpret the zig-zag belt as an inner layer of costal strips that has become interpolated between and tightly integrated with the anterior and posterior longitudinal costal strips. When describing lorica features in the text below we will refer to the 'mid-lorica zig-zag belt' or the 'mid-lorica panel of costal strips'.

The unfortunate existence of an electron microscope specific problem causing negatives to appear horizontally flipped, was discussed in Thomsen and $\varnothing$ stergaard (2019d). The evidence in favour of dealing with this problem as a purely technical issue is overwhelming. Scans of the affected negatives have accordingly been flipped horizontally to produce non-reversed images. In the current publication this applies to: Fig. 2a; Fig. 3a, b, h; Fig. 5a, i, j; Fig. 6a, e, f, n-q; Fig. 8a, b, d; Fig. 9i, j; Fig. 10a, f, j, k, q. 


\section{Results and discussion}

\section{Calotheca alata Thomsen and Moestrup, 1983 (Fig. 2)}

The tectiform genus Calotheca comprises a single species only (C. alata Thomsen and Moestrup, 1983) described from Indo-Pacific localities (Thomsen and Moestrup 1983). The conical lorica comprises 24 costal strips equally distributed within the external anterior transverse costa (6), two tiers of longitudinal costal strips (12), and an inner layer of costal strips (6) interpolated between the anterior and posterior longitudinal costal strips. The four components of costal strips differ markedly in size and shape (Thomsen and Moestrup 1983). All costal strips are flattened and comprise a conspicuous and heavily silicified midrib with lateral laminar flanges that are often patterned from perforations (Fig. 2a).

In C. alata there are elaborate interlocking devices that improve the cohesion of anterior transverse costal strips. While one end of the costal strip (left hand end when viewed from the outside of the lorica) is furnished with lateral ridges that in some specimens bend together almost forming a tube-like structure (see Thomsen and Moestrup 1983; loc. cit. Figs 7, 8), the other end is drawn into a snout-like projection that can slide into the 'tube-like' tip of the neighbouring costal strip. There is little doubt that the 'tube-like' structure at the left-hand end of an anterior transverse costal strip (when viewed from the outside of the lorica) is homologous to the unilateral spine that is a characteristic feature of e.g. most species of Stephanacantha (see further below).

The mid-lorica panel of costal strips comprises six obliquely oriented and spindle-shaped costal strips that each attach subapically to the inside of an anterior longitudinal costal strip while connecting with a lateral displacement to the anterior inside end of a posterior lorica chamber costal strip (Thomsen and Moestrup 1983). In the closely related genus Stephanacantha (Thomsen 
and Boonruang 1983) the mid-lorica segment is a zig-zag belt of spindle-shaped costal strips that unite and displace anterior and posterior longitudinal costal strips. Self-evidently this means that in Stephanacantha spp. there are twice as many mid-lorica costal strips as there are anterior and posterior longitudinal costal strips. Realizing that there are obvious morphological similarities between Calotheca and Stephanacantha that likely reflects a true phylogenetic kinship, it is possible to interpret the $C$. alata mid-lorica costal strip panel as a modified zig-zag belt formed by 'one-stranded' bifurcations (Thomsen and Moestrup 1983).

The material examined here complies with the Indo-Pacific material analysed by Thomsen and Moestrup (1983) both with reference to lorica dimensions (Table 1) and with respect to morphological features of the lorica (Fig. 2a). It is possible to recognize this species in the light microscope (Fig. 2b-g). An important diagnostic feature to look for is the very pronounced flanges on either side of an anterior longitudinal costal strip (Fig. 2c, f). It is in general not possible to establish details of the mid-lorica costal strip panel from light microscopy. The only known species that can be confused with C. alata is Stephanacantha campaniformis (Leadbeater, 1973) Thomsen in Thomsen and Boonruang, 1983. However, in this species the flanges on the longitudinal costal strips of the anterior chamber are narrower (Fig. 3f, g), and the zig-zag nature in this species of the mid-lorica segment often conspicuous (Fig. 3c-e). Finally, it should be added that while $C$. alata has never been observed with a compound pedicel, this is a common feature in specimens of $S$. campaniformis (Fig. 3a-f) from the oceanic warm water belt.

Distribution: Previously recorded from the Gulf of Elat, Red Sea (Thomsen 1978; referred to as Parvicorbicula campaniformis); Leigh, Kaikoura, and Portobello, New Zealand (Thomsen and Moestrup 1983); the Andaman Sea, Thailand (Thomsen and Moestrup 1983); Darwin, Shark Bay, and Sydney Harbour, Australia (Lee et al. 2003; Tong 1997; Tong et al., 1998); the South Atlantic 
coastal zone ( $\left.32^{\circ} \mathrm{S}\right)$ (Bergesh et al. 2008); the Beagle Channel, Patagonia (Thomsen, unpublished results). Here recorded from the Andaman Sea, Thailand, and West Australia (Table 2).

\section{Stephanacantha Thomsen in Thomsen and Boonruang, 1983}

This tectiform genus comprises species which are characterized by possessing flattened and sometimes quite elaborate costal strips organized to form a conical lorica. A transverse costa closes the lorica anteriorly, while there is in the mid-lorica region a zig-zag belt of costal strips uniting and laterally shifting the two tiers of longitudinal costal strips. Anteriorly the transverse and longitudinal costal strips form T-joints. A spine, located at the left-hand end of a transverse costal strip, when viewed from the outside of the lorica, is observed in most species. Costal strip numbers in each tier are typically a multiple of three.

Stephanacantha campaniformis (Leadbeater, 1973) Thomsen in Thomsen and Boonruang, 1983 (Figs. 3)

(Parvicorbicula campaniformis Leadbeater, 1973)

The Stephanacantha type species has elaborate costal strips, i.e. six anterior transverse costal strips, six anterior longitudinal costal strips, 12 mid-lorica costal strips forming a zig-zag belt, 12 posterior longitudinal costal strips, and two to four costal strips forming a compound pedicel. The exact number of posterior longitudinal costal strips cannot be ascertained from material available to us. However, it is evident (e.g. Fig. 3d, e) that these strips form a close armour around the protoplast, and it is most plausible that there is one longitudinal costal strip (six in total) attached to each pair of adjoining costal strips from the mid-lorica zig-zag belt, and an additional longitudinal costal strip (six in total) squeezed in alternating between these. This costal strip arrangement is partly confirmed by Leadbeater (1973; loc. cit. PI. 18a) and Booth (1990; loc. cit. 
Fig. 28). It should be noted that the apparently undamaged specimen illustrated in Fig. 3a has only five longitudinal costal strips in the anterior lorica chamber, whereas there are consistently six costal strips in other specimens illustrated (Fig. 3b-f). It is therefore most likely that a complete ' $T$ ' has been torn away from the specimen illustrated from TEM (Fig. 3a) during processing for microscopy.

While the anterior transverse costa is exterior, the zig-zag shaped belt of costal strips is interior relative to the longitudinal costal strips (Fig. 3a, b). The material examined here is characterized by distinctly triangular anterior transverse costal strips with a heavily silicified rib towards the inside of the lorica (Fig. 3h). A transverse patterning of perforations is most evident on the anterior larger lamina in near coastal material from the Gulf of California (Fig. 3a, b), whereas material from the Pacific Ocean (Fig. 3h) has more evenly distributed perforations. The opposite ends of an anterior transverse costal strip are obviously morphologically differentiated (Fig. 3a, b, h) with a snout-shaped right-hand end (viewed from the outside of the lorica) and a platform-shaped end which provides good contact with the snout from the neighbouring tip (Fig. 3h, arrows). The material from the Gulf of California examined here exactly mirrors part of the material examined by Leadbeater (1973; loc. cit. PI. 17b-e). Whereas a unilateral spine (left-hand end of costal strip when viewed from the outside of the lorica) was a characteristic feature in part of the material examined by Leadbeater (1973; loc. cit. PI. 17f) such spines were absent in material studied by Booth (1990; loc. cit. Fig. 28) and also in material examined here.

Anterior longitudinal costal strips are skittle-shaped and with a heavily silicified midrib and transverse ornamentations in the shape of perforations. Costal strips from the mid-lorica zig-zag belt are spindle shaped and with a more low-key ornamentation. Costal strips forming the posterior armour and the compound pedicel are very broad and tapering towards one end. 
Dimensions of S. campaniformis examined here (Table 1) are identical to those of the Adriatic Sea type material (Leadbeater 1973).

Leadbeater (1973; loc. cit. PI. 18a, b) reported the presence in some specimens of a short (1 $\mu \mathrm{m})$ and apparently nonmineralized flattened pedicel. This is an observation that we have not been able to confirm. However, it is appropriate here to draw attention to the presence in both $S$. dichotoma and S. formosa of similar nonmineralized posterior projections from the lorica. While a compound pedicel is a standard feature in material examined here, this was not reported in conjunction with the first description of this species.

A light microscopical recognition of this taxon is possible (Fig. 3c-g). The shape of anterior lorica chamber costal strips stands out clearly (e.g. Fig. 3f) and when dealing with empty loricae (e.g. Fig. 3c-e) the mid-lorica zig-zag belt as well as the posterior lorica chamber armour is visible.

Distribution: Previously recorded from Kastel Bay/Kotor Bay, Croatia/Montenegro, Adriatic Sea (Leadbeater 1973); Bay of Algiers, Mediterranean Sea (Leadbeater 1974); Kilsfjorden, Norway (Espeland and Throndsen 1986); subarctic North Pacific Ocean (Booth 1990); the Sound, Denmark (Thomsen et al. 2016); Beagle Channel, Patagonia (Thomsen, unpublished results). Here reported from the Gulf of California, Mexico, and the equatorial Pacific Ocean (Table 2).

\section{Stephanacantha oceanica sp. nov. (Fig. 4)}

Diagnosis: Lorica conical, $9.5 \mu \mathrm{m}$ in length, and with an anterior end diameter of $6 \mu \mathrm{m}$. The flagellum $(11 \mu \mathrm{m})$ reaches out of the lorica. Costal strips (6) from the anterior external ring (2.8.3.0 $\mu \mathrm{m}$ in length) form T-joints with longitudinal costal strips (5) that are 3.7-3.9 $\mu \mathrm{m}$ in length. Posteriorly these connect to pairs of short (1.8-2.1 $\mu \mathrm{m}$ long) costal strips from the zig-zag shaped mid-lorica belt of internal costal strips. The mid-lorica zig-zag belt thus comprises at least twice the 
number of costal strips as there are anterior longitudinal costal strips. Costal strips from the anterior transverse costa, the mid-lorica zig-zag belt, and the anterior tier of longitudinal costal strips are all narrow and partly flattened structures. Anterior longitudinal costal strips have spatulate tips. The anterior transverse costal strips are widened towards the middle and furnished with tip elaborations that aid interlocking of neighbouring strips. A short spine may be present at the left-hand costal strip end (viewed from the outside of the lorica). The posterior chamber is a complete armour of flattened and elaborate longitudinal costal strips (10-11). The individual strip is $3.7 \mu \mathrm{m}$ long and $0.6 \mu \mathrm{m}$ wide anteriorly. It tapers to a rod-shaped strip posteriorly. There is no posterior pedicel. Division is tectiform.

Holotype: The specimen illustrated in Fig. 4a of the present work is fixed as holotype (ICZN 1999, Article 73.1.4).

Type locality: A $30 \mathrm{~m}$ depth water sample $\left(17.9^{\circ} \mathrm{C}, 34.4 \mathrm{PSU}\right)$ collected $15 \mathrm{Jan} .2016$ from the Central South Pacific Ocean (39 $\left.18,569^{\prime} \mathrm{S}, 139^{\circ} 48,565^{\prime} \mathrm{W}\right)$.

Etymology: The species-group name is chosen to reflect the distribution of this species found mostly in open waters of warm oceans but not so far observed in coastal assemblages of loricate choanoflagellates.

The new species is described based on SEM micrographs of six partly complete cells (Fig. 4a, ce, g). There is a distinct match between S. campaniformis and S. oceanica when examining basic lorica morphometric details (Figs 3, 4 and Table 1). The difference that first and foremost justifies the description of a new taxon is the complete lack of laminar flanges on any S. oceanica costal strip from the anterior lorica chamber (Fig. 4a, g). Posterior lorica chamber costal strips appear to be almost identical in the two species. None of the $S$. oceanica cells available show any sign of 
having a pedicel, neither a short non-mineralized pedicel as reported by Leadbeater (1973) for the type material of S. campaniformis, nor a compound pedicel as observed in the vast majority of the warm water belt specimens of $S$. campaniformis examined here. It should be noted that the $S$. oceanica specimens illustrated in Fig. 4a, c-e, g have six anterior transverse costal strips but only five longitudinal costal strips in the anterior chamber. There is always a chance that costal strip losses occur during the manipulation of cells in preparation for microscopy. However, in this case where there are consistently five anterior longitudinal costal strips (this applies also to the LM images of the species; Fig. 4b, f), and also only five anterior peaks visible in the mid-lorica zig-zag belt in e.g. Fig. 4c, it appears safe to conclude that there is in fact a persistent mismatch in number between anterior lorica chamber costal strip components. A doubling of one mid-lorica costal strip is observed in some cells (Fig. 4a, c, arrows). While S. campaniformis specimens predominantly adhere to a costal strip sequence of 6:6:12:12, when enumerated from the lorica anterior end, the sequence in S. oceanica is best described as 6:5:10-(11):10-(11) where the number 11 in brackets identifies the possible presence of supernumerary costal strips.

While analysing material of S. campaniformis we came across cells from the Sargasso Sea and West Australia (Fig. 4b, f) that were at first sight classified as aberrant forms of this species. However, it is now obvious that these cells are likely more precisely identified as S. oceanica. They are smaller than S. campaniformis sensu stricto, and they have narrow anterior lorica chamber costal strips that adhere to a robust posterior lorica chamber.

Hoepffner and Haas (1990; loc. cit. Fig. 45) illustrates a partly damaged loricate choanoflagellate (identified as S. campaniformis) that is likely identical to S. oceanica, based in particular on the narrowness of anterior lorica chamber costal strips. While anterior transverse costal strips in our material are occasionally furnished with short unilateral spines (Fig. 4g; arrow), 
the North Pacific Central Gyre material also carries a fairly conspicuous spine at the left-hand end of each anterior transverse costal strip (when viewed from the outside of the lorica).

Distribution: Cells of S. oceanica are previously observed from the North Pacific Central Gyre (Hoepffner and Haas 1990; loc. cit. Fig. 45; identified as S. campaniformis). Here we report the species from the Central South Pacific Ocean (type locality), the Sargasso Sea, and West Australia. We propose that S. oceanica is adapted to low prey concentrations of warm open ocean rather than to highly-nutritious coastal waters.

\section{Stephanacantha dichotoma Thomsen in Thomsen and Boonruang, 1983 (Fig. 5)}

The typical S. dichotoma lorica comprises 18 costal strips. These are organized (Fig. 5a) as six anterior transverse costal strips, three anterior longitudinal costae, six mid-lorica costal strips forming a zig-zag belt, and three longitudinal costal strips that join posteriorly with a flattened and non-mineralized pedicel. The lorica is narrowly conical. Lorica dimensions as accounted for in Table 1 is in complete accordance with those of the Andaman Sea type material (Thomsen and Boonruang 1983).

Costal strips are flattened, narrow, and pattern less. There is a pronounced rib running along the entire length of a costal strip which indicates that the $S$. dichotoma costal strip is most likely triangular in cross section. Anterior transverse costal strips carry an upwardly pointing unilateral spine located at the left-hand end of the costal strip when viewed from the outside of the lorica

(Fig. 5i). The anterior longitudinal costal strips have spatulate anterior tips (Fig. 5i) where they join with the anterior transverse costal strips.

While most of the cells examined are in alignment with the description above, a certain variability with reference to in particular the number of longitudinal costae, was noticed in a small 
subset of specimens. A Pacific Ocean specimen (Fig. 5j) thus displays four longitudinal costal strips both anteriorly and posteriorly. Three longitudinal costal strips attach to neighbouring transverse costal strips (Fig. 5j; arrows) in the anterior ring of six transverse costal strips. It is anticipated that the mid-lorica zig-zag belt comprises eight costal strips although only seven of these are visible in Fig. 5j. The overall size of this specimen is identical to those that display the typical 6:3:6:3 costal strip configuration. Specimens with six anterior longitudinal costae (but still only three posterior longitudinal costal strips) have been observed in light microscopical preparations (Fig. $5 f, h$ ). These specimens are significantly larger than those with only three anterior longitudinal costae (Table 1). Thomsen and Boonruang (1983; loc. cit. Fig. 11) illustrated an Andaman Sea specimen with six anterior and three posterior longitudinal costal strips. However, this specimen was not dimensionally any different from cells with only three anterior longitudinal costae. It remains unclear how to deal with the variability encountered.

A light microscopical identification of S. dichotoma is straightforward (Fig. 5b-h). When examining empty loricae (Fig. 5k, I) all lorica constructional details can be verified.

Distribution: Previously reported from the Andaman Sea, Thailand (Thomsen and Boonruang 1983); the North Pacific Central Gyre (Hoepffner and Haas 1990); the subarctic North Pacific Ocean (Booth 1990; referred to as Stephanacantha cf. dichotoma); the equatorial Pacific Ocean (Vørs et al. 1995), the South Atlantic coastal zone ( 32 $\left.{ }^{\circ} \mathrm{S}\right)$ (Bergesh et al. 2008); and the Beagle Channel, Patagonia (Thomsen, unpublished results). Here reported from all sampling sites (Table 2). 


\section{Stephanacantha parvula Thomsen in Thomsen and Boonruang, 1983 (Figs. 6, 8)}

This species was originally described (Thomsen and Boonruang 1983) based on a somewhat limited material, i.e. eight cells in total, of which only two were studied in the electron microscope. It is fortunate that S. parvula has proved to be commonly observed in samples from the entire global warm water belt, which allows us to corroborate first of all the mere existence of this morphospecies, and more importantly to add further details to the morphological circumscription of the taxon.

The S. parvula lorica is conical, $9.6 \mu \mathrm{m}$ high on the average and with an anterior lorica end diameter of $6.6 \mu \mathrm{m}$ (Table 1). The flagellum often extends far out of the lorica (Fig. 6a-d, g, h). There is no site-specific pattern in size distribution (Fig. 7; open symbols). The lorica is in most cells examined constructed from 18 costal strips organized in a 6:3:6:3 pattern when examining tiers of costal strips from the anterior towards the posterior lorica end. Anterior lorica chamber costal strips are narrowly flattened and without neither a midrib nor transverse patterning. Costal strips occasionally tend to be slightly gutter-shaped. This is most evident in anterior transverse costal strips (Fig. 8c, d), and it is evident that the concave face of the costal strip is directed outwards. Anterior transverse costal strips carry a conspicuous unilateral spine (Fig. 6o, 8c, d) at the lefthand end when viewed from the outside of the lorica. Longitudinal costal strips have noticeable spatulate tips (Fig. 6e, o, 8c, d) that boosts the mechanical stability of anterior T-joints.

The costal strip configuration of the posterior lorica chamber and the morphological details of the individual strip were described very cautiously by Thomsen and Boonruang (1983). It is stated in the species diagnosis that 'the posterior lorica chamber is composed of three somewhat broader costal strips surrounding the protoplast'. The more recent Andaman Sea material examined here (Fig. 6e, f) clearly shows that the posterior longitudinal costal strip is broadly 
flattened anteriorly and displaying both a conspicuous midrib and a transverse patterning of perforations (Fig. 6f). The posterior longitudinal costal strip is attenuating in width towards the posterior lorica end to the extent that only the silicified midrib is preserved when the costal strips adjoin (Fig. 6e). All evidence suggests that there are only three longitudinal costal strips in the $S$. parvula posterior lorica chamber. Although less conspicuous it has also been verified from Pacific Ocean specimens (Fig. 6q, 8a, b) that the posterior chamber longitudinal costal strip is flattened anteriorly and posteriorly attenuating. A possibility remains that in some specimens (Fig. $6 n, p)$ the posterior longitudinal costal strip is morphologically more uniform from one end to the other and almost rod-shaped in appearance. However, realizing the inconspicuousness of the anterior end flattening (Fig. $6 q$ ) it must also be considered that even a minor tilt of a costal strip will cause this to appear rod-shaped when viewed in the electron microscope.

Stephanacantha parvula is easily recognized from light microscopy (Fig. 6b-d, g-m). When examining empty loricae of the species (Fig. 6i, j) it is possible to observe all lorica constructional details.

Distribution: Previously only reported from the Andaman Sea, Thailand (Thomsen and Boonruang 1983) and the Sargasso Sea (Davis and Sieburth, pers. comm.). Here reported from the Andaman Sea, Thailand, the equatorial Pacific Ocean, West Australia, the Caribbean Sea, and the Sargasso Sea (Table 2).

\section{Stephanacantha formosa Thomsen in Thomsen and Boonruang, 1983 (Fig. 9)}

This species shares basic features with other species of Stephanacantha, e.g. overall costal strip anatomy and the presence of an anterior transverse coata and a mid-lorica zig-zag shaped belt of strips, that separates and displaces two tiers of longitudinal costal strips. The funnel-shaped lorica 
(Fig. 9a, g) is posteriorly terminated by a long and flattened non-mineralized pedicel (e.g. Fig. 9c, d). See Table 1 for details on lorica dimensions. What clearly differentiates S. formosa from other species of Stephanacantha is the lack of numerical stability in lorica components (12-15 anterior transverse costal strips and 4-6 anterior longitudinal costal strips), and hence also a fortuitous location of joints between anterior transverse and longitudinal elements. The unilateral spines on anterior transverse costal strips (left-hand end when viewed from the outside of the lorica) are prominent structures furnished with a slight twist (Fig. 9i, j).

Not only do the anterior transverse costa vary with reference to the number of strips involved, with 12-13 strips being most frequently reported, but also the length of the individual strip is highly variable (Table 3). In eight specimens measured the average length is 3.95-4.30 $\mu \mathrm{m}$. However, the overall size range encountered is $2.75-5.45 \mu \mathrm{m}$. A costal strip type-specific size variability within the range of $15-30$ percent is commonly observed in loricate choanoflagellate species (Thomsen et al. 1990; see e.g. tabulated data for Crinolina aperta and Diaphanoeca multiannulata). Here the variability amounts on the average and in individual specimens (Table 3) to 65 percent (range: $46-98$ percent).

Recognition of S. formosa in the light microscope (Fig. 9a-h) is straightforward and can be corroborated from just a small segment of the highly unique anterior transverse costa Distribution: Previously reported from the Andaman Sea, Thailand (Thomsen and Boonruang 1983); Japan and Taiwan (Hara et al. 1997); the equatorial Pacific Ocean (Vørs et al. 1995); Galapagos coastal waters (I. Manton, personal communication). Here reported from all sites sampled (Table 2). 
Stephanacantha zigzag (Thomsen in Thomsen et al., 1991) comb. nov. (Fig. 10a-j)

(Protonym: Parvicorbicula zigzag Thomsen in Thomsen et al., 1991)

This is a clearly defined species that in an undisturbed lorica has an anterior ring formed by 8 transverse costal strips (Fig. 10a). Every second of these attaches ('T-joint') to a longitudinal costal strip which posteriorly attaches to the upper nodes of a mid-lorica zig zag belt ( 8 costal strips). Four longitudinal costal strips similarly attach to the lower nodes of this belt and adjoin at the posterior lorica end. In Pa. zigzag there are thus, as in Stephanacantha spp., no longitudinal costae that run uninterrupted from the anterior to the posterior lorica end, and there are only two tiers of longitudinal costal strips. The anterior tip of a longitudinal costal strip is at the anterior lorica end furnished with rather indistinct biforked terminations. All costal strips are narrow rods. Lorica dimensions are included in Table 1. There is no site-specific variability (Fig. 7; filled symbols). As is apparent from Fig. 10b-e, g-i this species is easily recognized in the LM.

It has been evident for some time (Leadbeater 2015) that the circumscription of both Pleurasiga Schiller, 1925, and Parvicorbicula Pavillard, 1960, is jeopardized. It is possible to define a small core group of species across the genus boundaries (i.e. Pa. socialis, Pa. quadricostata, Pa. circularis, Pl. minima, PI. reynoldsii, PI. tricaudata) that will most likely prove to be phylogenetically valid once tested using molecular tools. Thomsen et al. (2020) refrained from formally reorganizing the genera, mainly because the genus Parvicorbicula additionally comprises a whole range of taxa that are temporarily dumped here in the lack of a better choice. While a focused circumscription of the cluster of taxa mentioned above under a Parvicorbicula umbrella and with reference to the Parvicorbicula type species, Pa. socialis (Meunier, 1910) Pavillard, 1960, will help solving e.g. the Pleurasiga enigma (see Thomsen et al. 2020 for further details), it will 
simultaneously also enhance the obvious heterogeneity that currently applies to the genus Parvicorbicula as a whole.

Parvicorbicula zigzag (Thomsen et al. 1991) differs from the core group of Parvicorbicula spp. by having only two versus three tiers of longitudinal costal strips, and by having no longitudinal costae that run uninterrupted the entire length of the lorica. In Pa. zigzag the mid-lorica zig-zag belt of costal strips displaces anterior and posterior longitudinal costal strips. From a lorica constructional point of view Pa. zigzag is thus completely identical to S. parvula. Features distinguishing the two taxa are the presence of only rod-shaped costal strips in Pa. zigzag, and the fact that the lorica base variable is four in Pa. zigzag (i.e. 8:4:8:4 costal strips in the anterior to posterior tiers of strips) and three in S. parvula (i.e. 6:3:6:3). While the lorica height is much the same in the two species (Fig. 7) the diameter at the level of the anterior transverse costa is significantly larger in S. zigzag, perhaps simply reflecting the fact that the number of transverse costal strips is here increased by two.

Distribution: Previously reported from central Californian waters, USA (Thomsen et al. 1991), North Pacific Central Gyre (Hoepffner and Haas 1990; referred to as Parvicorbicula quadricostata), and the Beagle Channel, Patagonia (Thomsen, unpublished results). Here we add findings from all sampling sites (Table 2).

Syndetophyllum pulchellum (Leadbeater, 1974) Thomsen and Moestrup, 1983 (Fig. 10k-q) (Parvicorbicula pulchella Leadbeater, 1974)

Syndetophyllum Thomsen and Moestrup, 1983, is a monotypic genus characterized by remarkably elaborate costal strips of four types. The tiny lorica comprises two transverse costae (i.e. an anterior ring and a mid-lorica transverse costa), two tiers of longitudinal costal strips, and a 
compound pedicel. Due to the small size of the lorica (Table 1) and the compactness of the elaborate costal strips it has been, and still remains, a problem to exactly quantify the number of strips forming part of each costal strip array. While the type description (Leadbeater 1974) refers to the presence of 10 longitudinal costal strips both anteriorly and posteriorly, there is no attempt to quantify the number of transverse costal strips. Thomsen and Moestrup (1983) finds, based on the fortunate availability of two empty loricae, that the anterior transverse costa comprises 16 costal strips, while there are eight anterior longitudinal costal strips, and at least 12 (perhaps even 16) costal strips present in the mid-lorica transverse costa. The posterior lorica chamber is found to comprise 12 costal strips, while the compound pedicel usually has four costal strips. One of the cells examined here (Fig. 10k) does confirm that 16 transverse costal strips are forming part of the anterior ring. However, in other cells examined both from the Andaman Sea and the Gulf of California (Fig. 10q) the number of strips involved is 12-13. In our material the number of longitudinal costal strips both anteriorly and posteriorly is around eight.

While other taxa treated here are characterized by a mid-lorica belt of obliquely oriented costal strips, forming in the case of Stephanacantha spp. a zig-zag belt, it appears that the S. pulchellum mid-lorica costal strips are placed perpendicular to the longitudinal axis of the cell (Fig. 10k, q; see also Thomsen and Moestrup (1983; loc. cit. Figs 11, 15) forming a bona fide transverse costa(e).

The upturned midrib and the pointed termination of a transverse costal strip is beyond doubt the equivalent of a spine. The 'spine' is at the left-hand end of a transverse costal strip when viewed from the outside of the lorica (Fig. 10k, q), and in this respect thus similar to species of Stephanacantha.

Despite the modest lorica dimensions the recognition of S. pulchellum from light microscopy is straightforward (Fig. 10l-p). 
Distribution: Previously reported from the Bay of Algiers, Mediterranean Sea (Leadbeater 1974); the Gulf of Elat, Red Sea (Thomsen 1978); Leigh, New Zealand (Moestrup 1979); the Andaman Sea, Thailand (Thomsen and Moestrup 1983); the East Australian Current (Hallegraeff 1983); Taiwan (Hara et al. 1997); Sydney Harbour, Australia (Tong et al. 1998); the South Atlantic coastal zone $\left(\sim 32^{\circ} \mathrm{S}\right)$ (Bergesh et al. 2008); Pettaquamscutt River, Rhode Island, USA (Menezes 2005). Here we report findings of Syndetophyllum pulchellum from four out of seven regions sampled

\section{Conclusions}

The tectiform genera discussed here share multiple features rendering it likely that they will eventually, once the appropriate molecular tools have been applied, be found to be phylogenetically closely related. Shared morphological features encompass e.g. (1) the mostly elaborate nature of costal strips involved, (2) the presence of two transversely placed groups of costal strips (i.e. an anterior external and ring-shaped transverse costa and either an internal midlorica zig-zag belt (Stephanacantha spp.), a one-stranded reduced version of this (Calotheca alata), or a genuine mid-lorica transverse costa(e) (Syndetophyllum pulchellum)), and two tiers of longitudinal costal strips forming the anterior and posterior lorica chambers respectively, (3) the occurrence in several species of the number three as a pivoting figure in lorica numerical aspects, and (4) the repeated occurrence of anterior spines, or spine-like derivatives, at the left-hand end (when viewed from the outside) of transverse costal strips.

The chance to revisit these genera has in general corroborated the circumscription of genera as outlined by Thomsen and Moestrup (1983) and Thomsen and Boonruang (1983). Yet, in retrospect it might appear as if the genus Calotheca is in fact superfluous because the re-examination of $C$. alata and S. campaniformis has seriously underpinned the similarities, rather than the differences 
between these two species. It still appears relevant to maintain a certain taxonomic distance between on the one hand Syndetophyllum pulchellum and on the other hand species of Calotheca and Stephanacantha.

The transfer of Parvicorbicula zigzag to the genus Stephanacantha is carried out with some degree of hesitation, mostly because it interacts with the first circumscription of the genus that excludes species that do not have broad costal strips. However, it is in our opinion to be anticipated that lorica constructional details will turn out to be more decisive in a phylogenetic context than the actual elaboration of individual costal strips. A similar case exists with reference to the genera Cosmoeca Thomsen in Thomsen and Boonruang, 1984 and Thomsenella Özdikmen, 2009 (= Platypleura Thomsen in Thomsen and Boonruang 1983) where lorica constructional details are similar, and the genera most likely artificially separated based only on the involvement of standard rod-shaped costal strips (Cosmoeca spp.) versus flat and elaborate costal strips (Thomsenella spp.)

In genera dealt with here the anterior costal strip spine is located at the left-hand end of the costal strip when viewed from the outside of the lorica. This is opposite to what was found in several species of Pleurasiga (Thomsen et al. 2020) where the spine is located at the right-hand end. It should be emphasized that in Pleurasiga spp. the mid-lorica costa is external relative to the longitudinal costae and also that costal strip joint patterns are here reversed (Thomsen et al. 2020) with reference to the established norm within loricate choanoflagellates (Leadbeater 2015). This seems to imply that the reversal of symmetry that has been documented with reference to the mid-lorica transverse costa in species of Pleurasiga also applies to the anterior transverse costa. Spines observed in species of Stephanacantha are not subterminal as observed in species of 
Pleurasiga (Thomsen et al. 2020) and on the whole quite different from the prong-like configuration as described in e.g. Pleurasiga echinocostata (Thomsen et al. 2020).

The true nature of the mid-lorica zig-zag belt in species of Stephanacantha remains an enigma. Most evidence points to that the zig-zag belt is after all homologous to a transverse costa. Two steps, i.e. a removal of every second costal strip and a flattening of the entire structure, will be needed in species of Stephanacantha to produce the image of a standard transverse costa that 'interact precisely with longitudinal costae with which they have clearly definable junctions' (Leadbeater 2015). In an evolutionary context this means that a costal strip duplication must have occurred followed by a reorganization of strips that meticulously integrates longitudinal and transverse elements in the mid-lorica region.

\section{Author contribution statement}

Helge A. Thomsen (HAT) has undertaken a major part of the sampling activities and the subsequent microscopical analyses. HAT is further responsible for compiling and writing the paper. Jette B. Østergaard (JBO) has been much involved in the Andaman Sea and the Pacific Ocean sampling. JBO has also carried out part of the transmission electron microscopical examination of these samples. Nina A. Kamennaya (NAK) and Mikhail V. Zubkov (MVZ) have provided SEM images of S. oceanica and commented on drafts of the manuscript.

\section{Acknowledgements}

Crew and scientists on board the research vessels ('Dana', 'Vaedderen', 'Chakratong Tongyia', 'Malcolm Baldrige', 'Sonne') are acknowledged for good collaborative spirit and for providing excellent facilities for collecting and processing our samples. Dr. Gunni ÆErtebjerg and Steffen 
Mariager Pedersen are acknowledged for providing the samples from outside the Alexandria Harbour. We are grateful to Dr. Sergio Sanudo-Wilhelmy and Kurt Buck for organizing the trip to Gulf of California. Carol Kosman is warmly acknowledged for her meticulous contribution to this paper. We thank Drs. Tomasz Goral and Alex Ball from the Natural History Museum, London for support with the electron microscopy imaging. Thanks are due to an anonymous reviewer for pointing out the need for a more stringent terminology to be used when describing the mid-lorica zig-zag belt of costal strips. Main funding sources, i.e. the Independent Research Fund Denmark, the Carlsberg Foundation, Danida (Denmark's development cooperation), the Højgaard Foundation, and the Danish Centre for Marine Research are acknowledged for their generous contributions to our research. The present work was carried out as part of the Galathea3 expedition under the auspices of the Danish Expedition Foundation (Galathea3 contribution no. P131), as part of the Sargasso-Eel 2014 Expedition, as part of the UltraPac Expedition funded by the Federal Ministry of Education and Research of Germany (grant 03G0245A) on board Research Vessel 'Sonne' (SO-245). The research on the SO-245 cruise was supported by the UK Natural Environment Research Council through Research grant NE/M014363/1. 


\section{References}

Bergesch, M., Odebrecht, C., Moestrup, $\varnothing ., 2008$. Loricate choanoflagellates from the South Atlantic coastal zone $\left(\sim 32^{\circ} \mathrm{S}\right)$ including the description of Diplotheca tricyclica sp. nov. Biota Neotrop 8, 111-122.

Booth, B.C., 1990. Choanoflagellates from the subarctic North Pacific Ocean, with description of two new species. Can. J. Zool. 68, 2393-2402.

Espeland, G., Throndsen, J., 1986. Flagellates from Kilsfjorden, southern Norway, with description of two new species of Choanoflagellida. Sarsia 71, 209-226.

Hallegraeff, G.M., 1983. Scale-bearing and loricate nanoplankton from the East Australian Current. Bot. Marina, 26, 493-515.

Hara, S., Sheu, J., Chen, Y.L., Takahashi, E., 1997. Choanoflagellates (Sarcomastigophora, Protozoa) from the coastal waters of Taiwan and Japan (II): Species composition and biogeography. Zool. Stud. 36, 98-110.

Hoepffner, H., Haas, L.W., 1990. Electron microscopy of nanoplankton from the North Pacific central gyre. J. Phycol. 26, 421-439.

ICZN 1999. International Code of Zoological Nomenclature, Fourth Edition: The International Trust for Zoological Nomenclature, London, UK, $306 \mathrm{pp}$.

Kamennaya, N.A., Kennaway, G., Fuchs, B.M., Zubkov, M.V., 2018. “Pomacytosis” - Semiextracellular phagocytosis of cyanobacteria by the smallest marine algae. PLOS Biol. 16, e2003502, doi: 10.1371/journal.pbio.2003502. 
Leadbeater, B. S. C. 1973. External morphology of some marine choanoflagellates from the coast of Jugoslavia. Arch. Protistenk. 115: 234-252.

Leadbeater, B.S.C., 1974. Ultrastructural observations on nanoplankton collected from the coast of Jugoslavia and the Bay of Algiers. J. mar. biol. Ass. U.K. 54, 179-196.

Leadbeater, B.S.C., 2015. The Choanoflagellates: Evolution, biology and ecology. Cambridge University Press.

Lee, W.J., Brandt, S.M., Vørs, N., Patterson, D.J., 2003. Darwin's heterotrophic flagellates. Ophelia 57, 63-98.

Menezes, S., 2005. Nanoplankton biodiversity in the Pettaquamscutt river estuary, Rhode Island, U.S.A. PhD thesis, Univ. Rhode Island, 319pp.

Moestrup, $\varnothing ., 1979$. Identification by electron microscopy of marine nanoplankton from New Zealand, including the description of four new species. New Zeal. J. Bot. 17, 61-95.

Moestrup, $\varnothing$., Thomsen, H.A., 1980. Preparation of shadow-cast whole mounts. In: Gantt, E. (Ed.), Handbook of Phycological methods. Vol. III. pp. 385-390 (Cambridge).

Thomsen, H.A. 1978. Nanoplankton from the Gulf of Elat (= Gulf of Aquaba), with particular emphasis on the choanoflagellates. Isr. J. Zool. 27, 34-44.

Thomsen, H.A., 1982. Planktonic choanoflagellates from Disko Bugt, West Greenland, with a survey of the marine nanoplankton of the area. Meddr. Grønland, Bioscience 8, 1-35.

Thomsen, H.A., Boonruang, P., 1983. A microscopical study of marine collared flagellates (Choanoflagellida) from the Andaman Sea, SW Thailand: Species of Stephanacantha gen. nov. and Platypleura gen. nov. Protistologica 19, 193-214. 
Thomsen, H.A., Buck, K R., 1991. Choanoflagellate diversity with particular emphasis on the Acanthoecidae. In: Patterson, D.J., Larsen, J. (Eds.), Free-living heterotrophic flagellates. Clarendon Press, Oxford, pp. 259-284.

Thomsen, H.A., Moestrup, $\varnothing ., 1983$. Electron microscopical investigations on two loricate choanoflagellates (Choanoflagellida), Calotheca alata gen. et sp. nov. and Syndetophyllum pulchellum gen. et comb. nov., from Indo-Pacific localities. Proc. R. Soc. Lond. B 219, 41-52.

Thomsen, H.A., Østergaard, J.B., 2019a. Loricate choanoflagellates (Acanthoecida) from warm water seas. I. Conioeca gen. nov. and Nannoeca Thomsen. Eur. J. Protistol. 67, 77-88.

Thomsen, H.A., Østergaard, J.B., 2019b. Loricate choanoflagellates (Acanthoecida) from warm water seas. II. Bicosta, Apheloecion, Campyloacantha and Saroeca. Eur. J. Protistol. 67, 114-131. Thomsen, H.A., Østergaard, J.B., 2019c. Loricate choanoflagellates (Acanthoecida) from warm water seas. III. Acanthocorbis Hara and Takahashi and Stephanoeca Ellis. Eur. J. Protistol. 69, 52-69.

Thomsen, H.A., Østergaard, J.B., 2019d. Loricate choanoflagellates (Acanthoecida) from warm water seas. IV. Cosmoeca Thomsen. Eur. J. Protistol. 71, pp. 125632

Thomsen, H.A., Østergaard, J.B., 2019e. Loricate choanoflagellates (Acanthoecida) from warm water seas. V. Thomsenella Özdikmen (= Platypleura Thomsen). Eur. J. Protistol. 71, pp. 125632 Thomsen, H.A., Buck, K.R., Coale, S.L., Garrison, D.L., Gowing, M.M., 1990. Loricate choanoflagellates (Acanthoecidae, Choanoflagellida) from the Weddell Sea, Antarctica. Zool. Scr. 19, 367-387.

Thomsen, H.A., Buck, K.R., Chavez, F.P., 1991. Choanoflagellates of the central California waters: Taxonomy, morphology and species assemblages. Ophelia 33, 131-164. 
Thomsen, H.A., Nitsche, F., Richter, D.J., 2016. Seasonal occurrence of loricate choanoflagellates in Danish inner waters. Protist 167, 1-17.

Thomsen, H.A., Kamennaya, N., Zubkov, M.V., Østergaard, J.B., 2020. Loricate choanoflagellates (Acanthoecida) from warm water seas. VI. Pleurasiga Schiller and Parvicorbicula Deflandre. Eur. J. Protistol. (in press).

Tong, S.M., 1997. Heterotrophic flagellates from the water column in Shark Bay, Western Australia. Mar. Biol. 128, 517-536.

Tong, S.M., Nygaard, K., Bernard, C., Vørs, N., Patterson, D.J., 1998. Heterotrophic flagellates from the water column in Port Jackson, Sydney, Australia. Eur. J. Protistol. 34, 162-194.

Vørs, N., Buck, K.R., Chavez, F.P., Eikrem, W., Hansen, L.E., Østergaard, J.B., Thomsen, H.A., 1995. Nanoplankton of the equatorial Pacific with emphasis on the heterotrophic protists. Deep-Sea Research 42, 585-602. 
Fig. 1. Map showing the approximate sampling sites for material reported here and MODIS sea surface temperatures (2003-2011 average). A circular dot refers to a single spot sampling, while a line or square indicates that samples were collected along extended transects. A black open square shows the approximate location of the South Pacific sampling sites. For further information see the materials and methods section in Thomsen and $\varnothing$ stergaard (2019a).

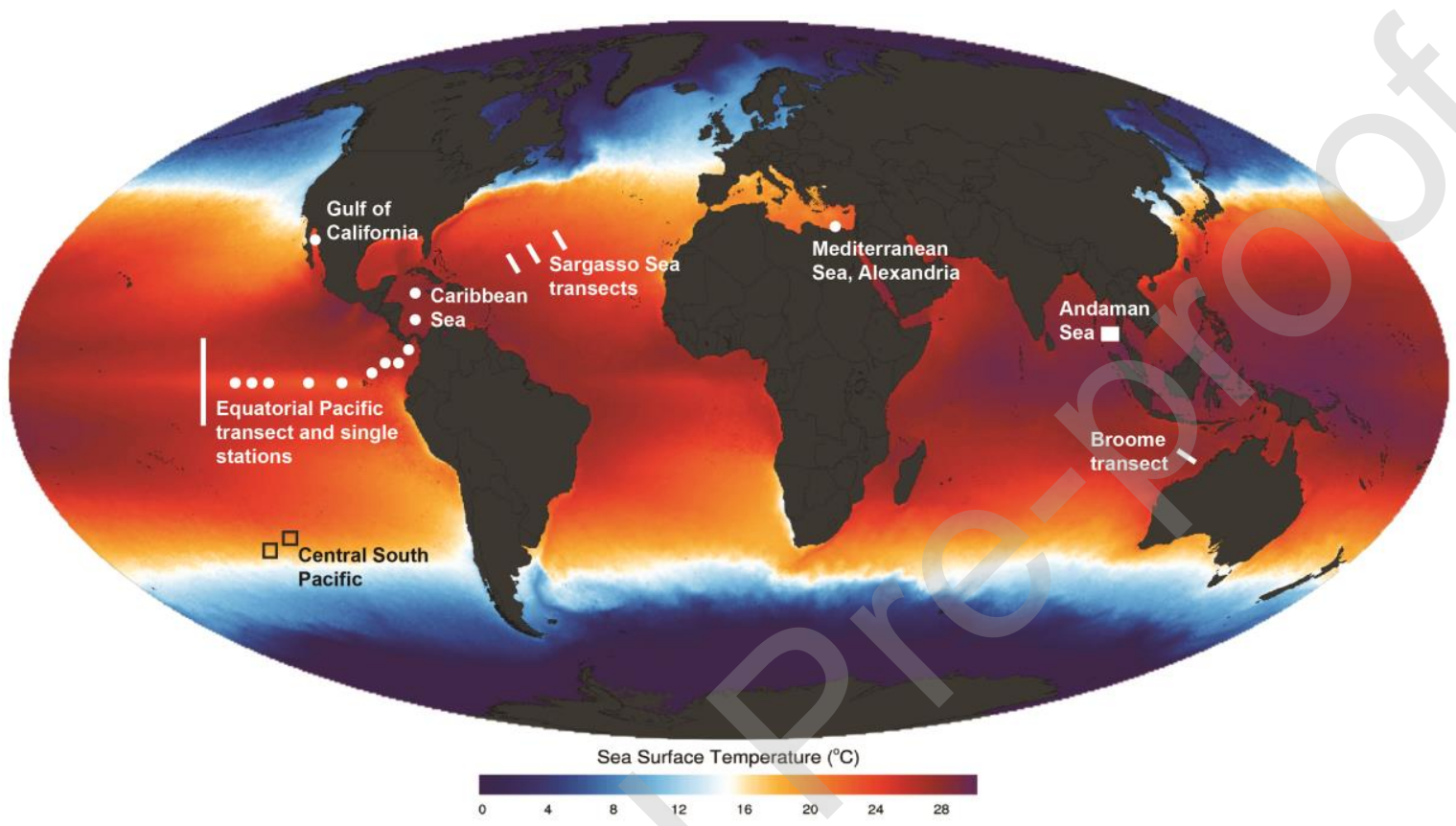

Fig. 2.a-g. Calotheca alata TEM (a) and LM (b-g; phase contrast) whole mounts from the Andaman Sea, Thailand (a) and West Australia (b-g). (a) Complete lorica with intact protoplast showing basic lorica features; (b-g) Selected light micrographs to illustrate the diversity encountered; the characteristic costal strip flanges are easily visible. The scale bar (f) applies to all LM images. 

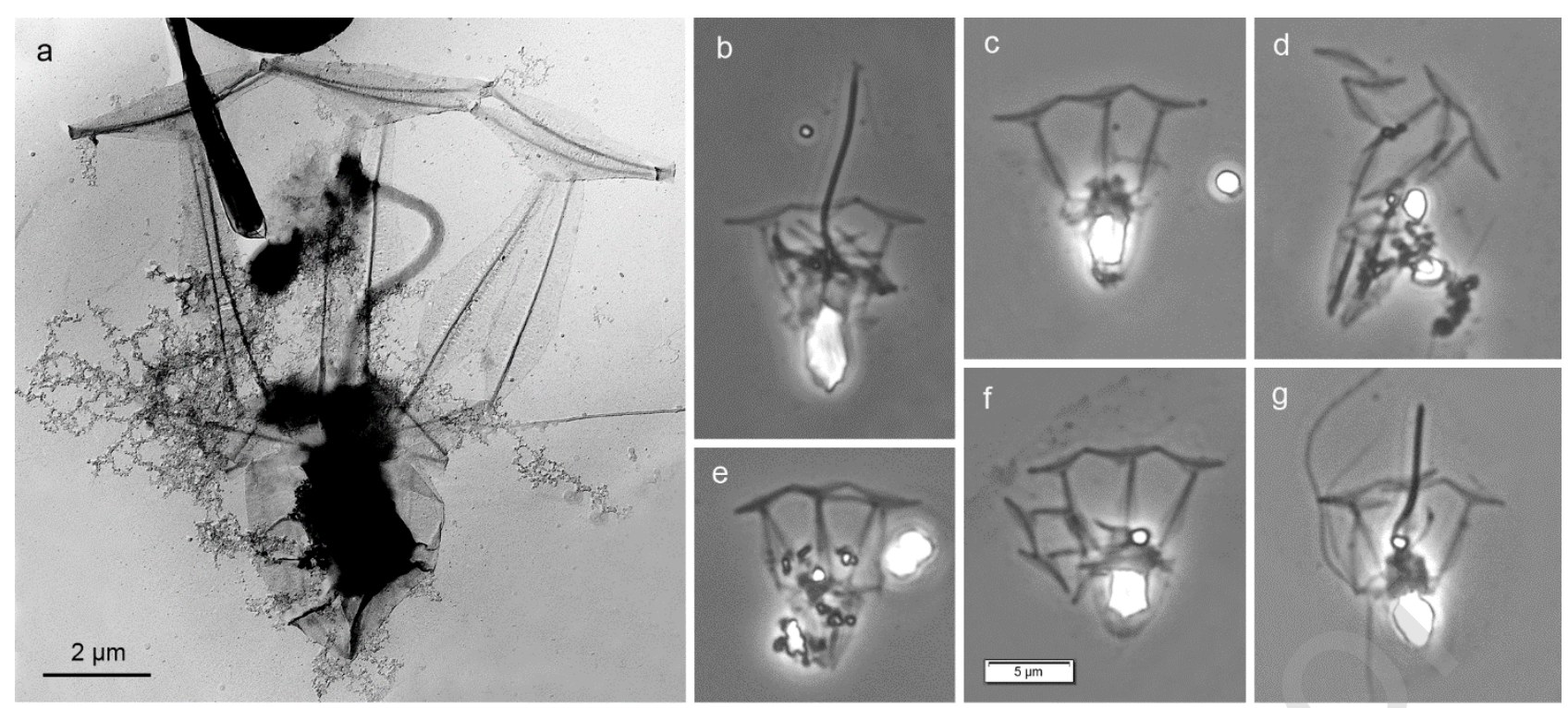

Fig. 3.a-h. Stephanacantha campaniformis TEM (a, b, h) and LM (c-g; phase contrast) whole mounts from the Gulf of California (a-f) and the equatorial Pacific Ocean ( $g, h) .(\mathbf{a}, \mathbf{b})$ Loricae 
showing basic constructional details and costal strip features; notice (b) the accumulation of costal strips from the mid-lorica zig-zag belt in the collar region; (c-g) Selection of specimens from various geographic regions; (h) Detail of anterior transverse costa; the arrows point to special interlocking modifications of opposing costal strip terminations. The scale bar (d) applies to all LM images.

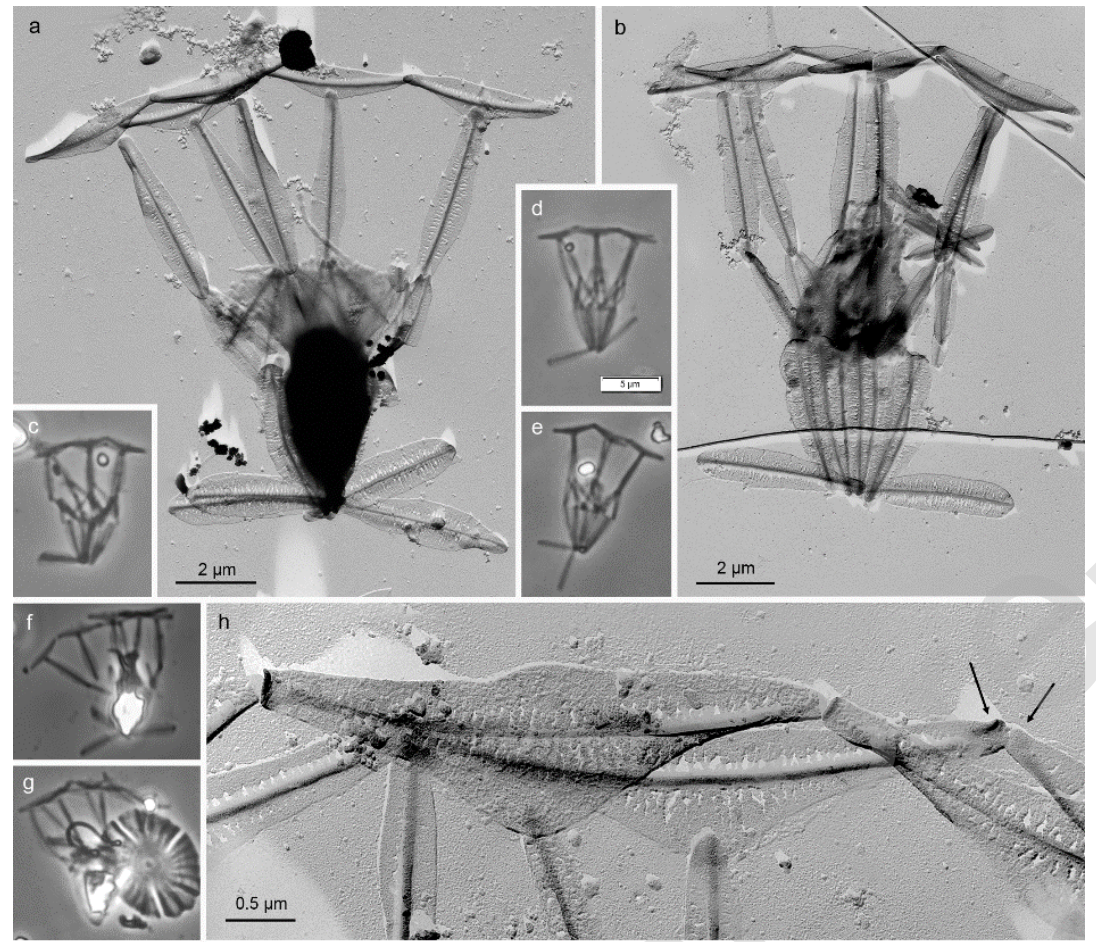

Fig. 4.a-h. Stephanacantha oceanica SEM (a, c-e, g, h) and LM (b, f; phase contrast) whole mounts from the Central South Pacific Ocean (a, c-e, g, h), the Sargasso Sea (b), and West Australia (g). (a) Complete cell (holotype); lorica showing basic constructional details and costal strip features; the arrow points to a costal strip duplication; (b) Empty cell with five anterior longitudinal costal strips; notice that one of these is bent down; (c) Complete cell with costal strip duplication (arrow) 
in the mid-lorica zig-zag shaped belt; (d, e) Complete cells; (f) Cell with intact protoplast and costal strips that appear slightly more elaborate than those observed in (b); (g) Partly damaged complete cell; the arrow points to a short anterior spine; costal strips from the mid-lorica zig-zag belt are accumulating in the collar region; (h) Detail (from g) of posterior lorica chamber costal strips. The scale bar (b) applies to all LM images. 


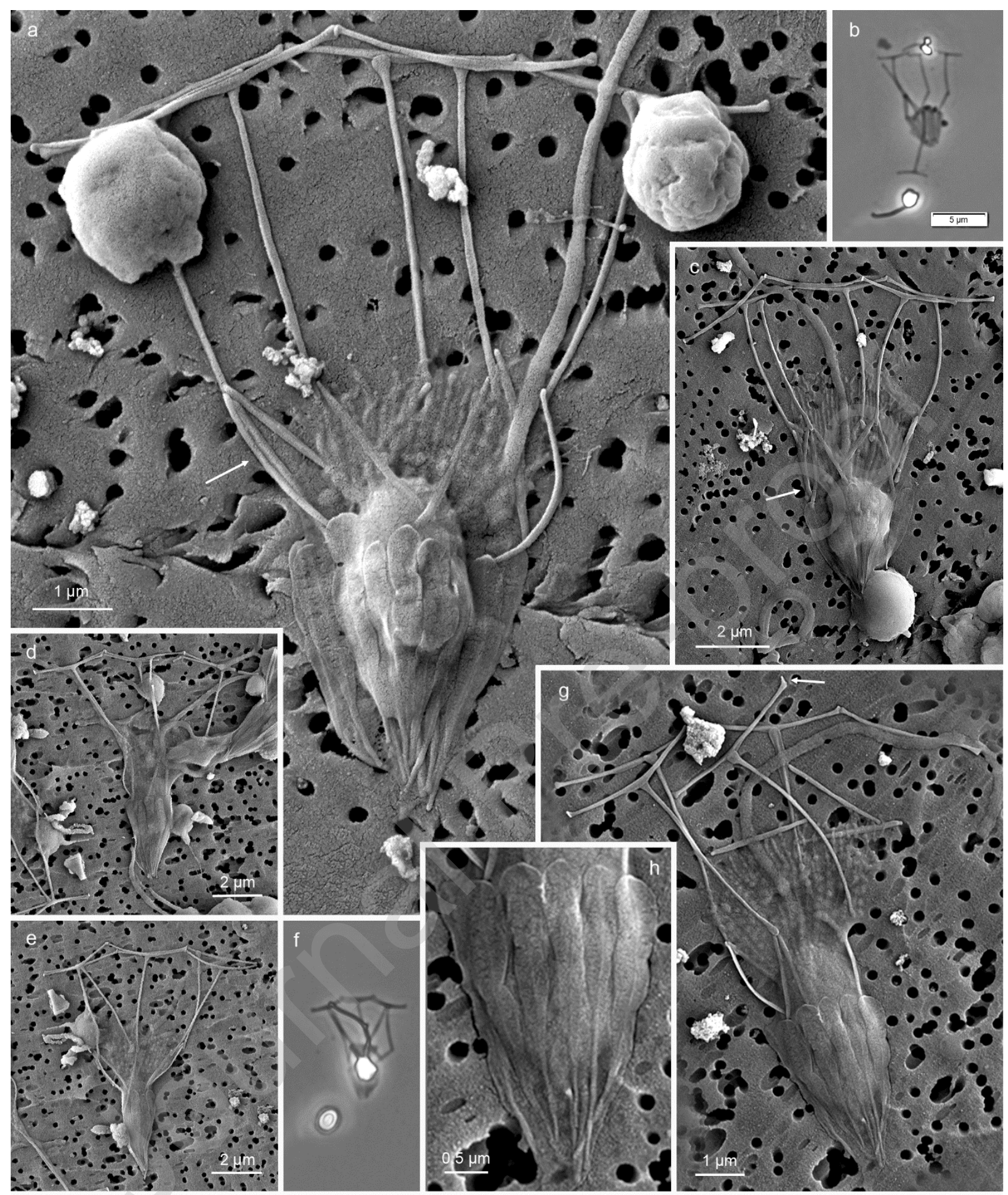

Fig. 5.a-I. Stephanacantha dichotoma TEM $(a, i, j)$ and LM (b-h, k, l; phase contrast) whole mounts from the Andaman Sea, Thailand (a), the Sargasso Sea (b), the equatorial Pacific Ocean (c, i, j), the 
Caribbean Sea (d), the Gulf of California, Mexico (e, f) and West Australia (g, h, k, I). (a) Complete cell showing basic lorica features; notice the apparently unmineralized posterior pedicel and the presence of three longitudinal costal strips at both the anterior and posterior lorica end; (b-h, $\mathbf{k}, \mathbf{l})$ Selected specimens to show the variability encountered; (i) Detail (reversed printing) from (j); notice that the transverse costa is exterior relative to the longitudinal costal strips and that the prominent spine is on the left-hand end of the transverse costal strip when viewed from the outside; (j) Complete cell with four longitudinal costal strips at both the anterior and posterior lorica end; arrows point to T-joints on three neighbouring strips. The scale bar (b) applies to all LM images. 


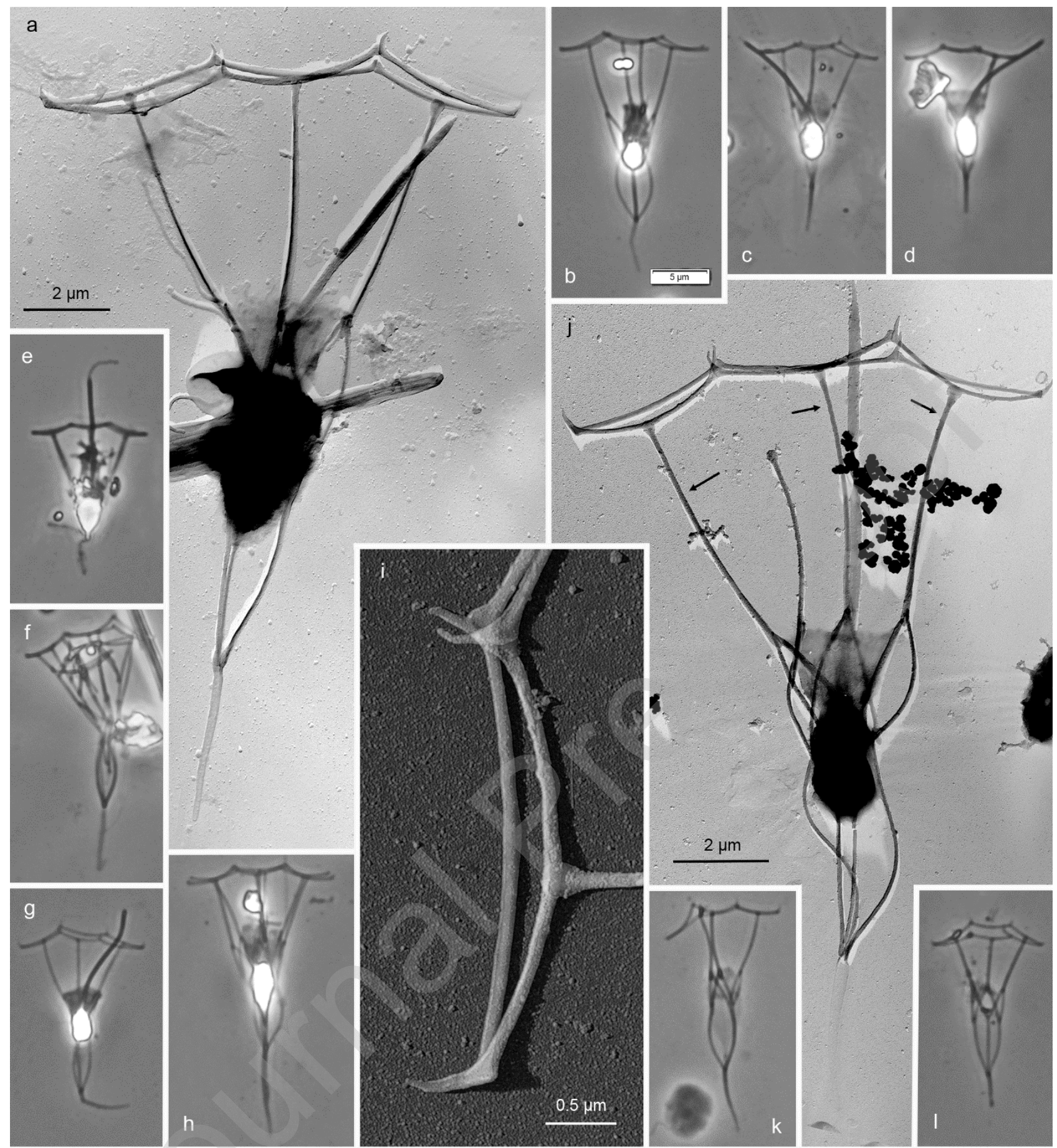

Fig. 6.a-q. Stephanacantha parvula (TEM (a, e, f, n-q) and LM (b-d, g-m; phase contrast) whole mount micrographs from the Andaman Sea, Thailand (a, e, f), the equatorial Pacific Ocean (b, c, I- 
q), the Caribbean Sea (d), the Sargasso Sea (g), and West Australia (h-k). (a) Complete cell with protoplast, collar and flagellum; observe that the longitudinal costal strips when adjoining posteriorly are narrow rods; notice that costal strips from the mid-lorica zig-zag belt are accumulating in the collar region (b-d, g-m) Selected specimens to show the variability encountered; the empty loricae $(i, j)$ clearly display all diagnostic features of the species; (e) Complete cell; the posterior lorica chamber is composed of anteriorly flattened longitudinal costal strips; (f) Detail from (e) to show the flattened and posteriorly sharply tapering costal strip from the posterior lorica chamber; $(\mathbf{n}, \mathbf{p})$ Complete specimens; (o) Detail of anterior transverse costal strip to show the very prominent unilateral spines; (q) Posterior lorica chamber costal strip which is broadly flattened anteriorly and attenuating towards the posterior end. The scale bar (i) applies to all light micrographs. 


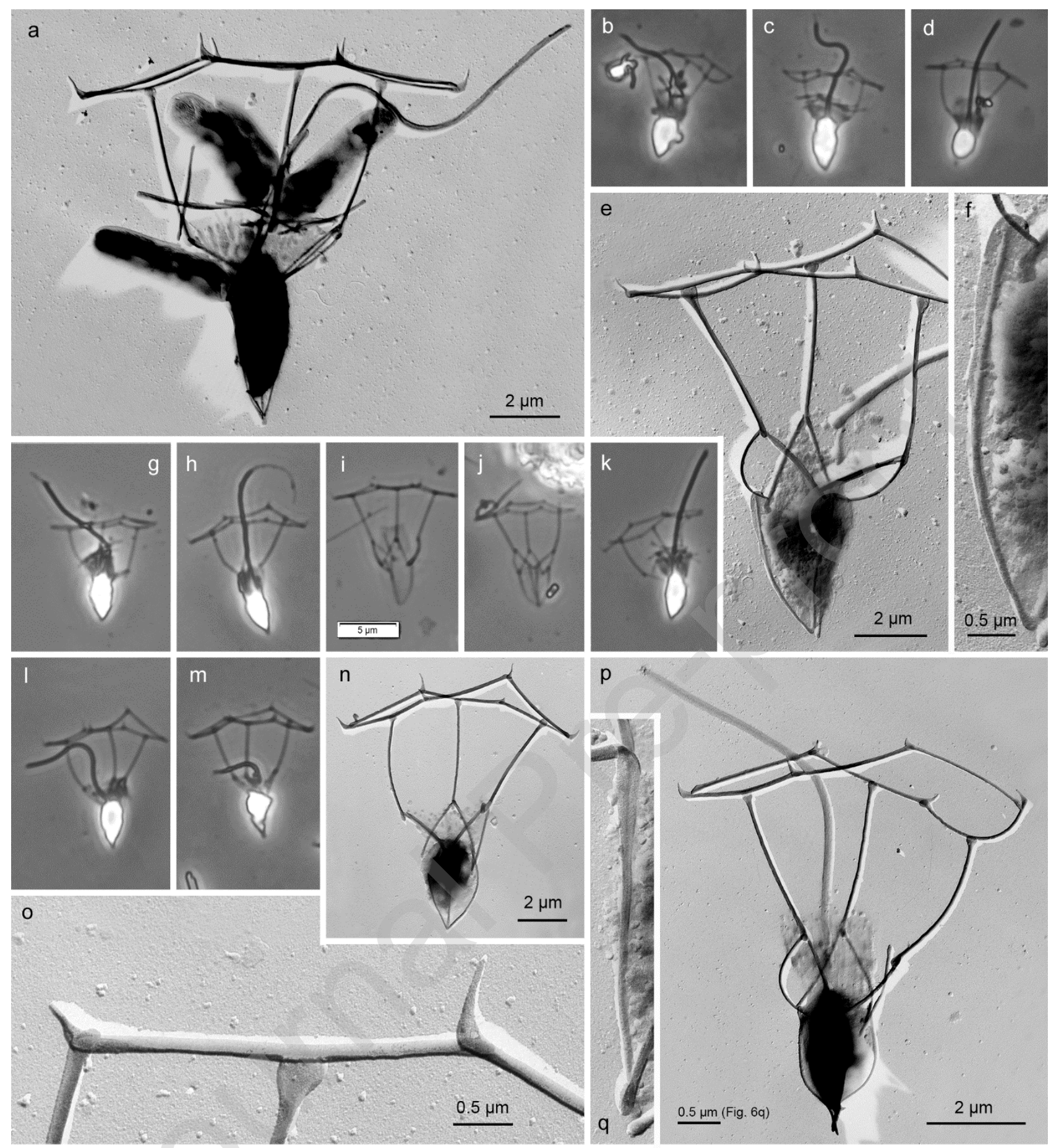


Fig. 7. Diagram illustrating the site-specific variability in size (lorica height versus anterior lorica end diameter) for S. parvula (empty symbols) and S. zigzag (filled symbols).

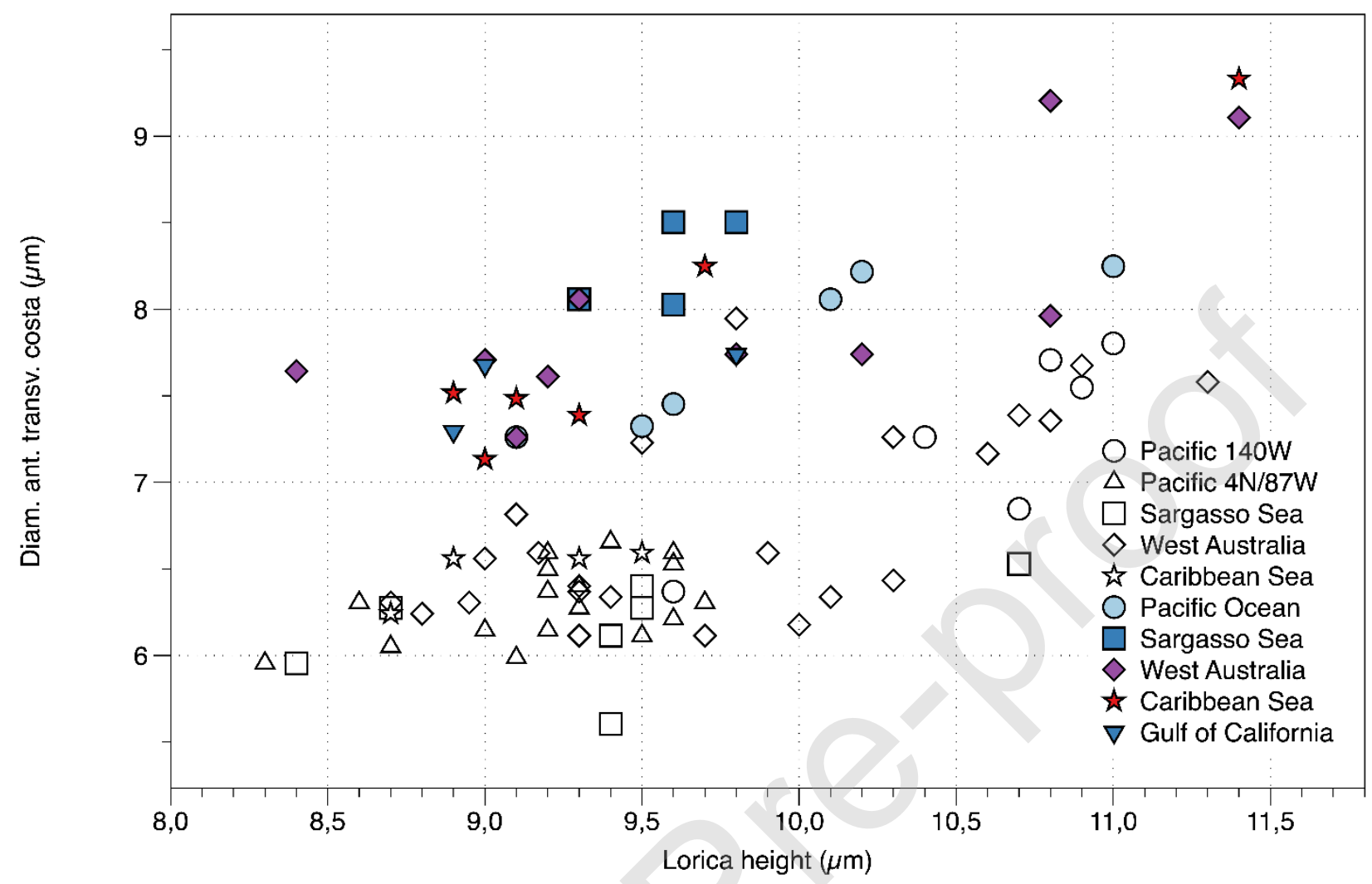

Fig. 8.a-d. Stephanacantha parvula TEM whole mount micrographs from the equatorial Pacific

Ocean (a, b) and the Andaman Sea, Thailand (c, d). (a) Complete cell (reversed printing); (b) Detail from (a) to show the longitudinal costal strips surrounding the protoplast. The arrow points to the flattened anterior end of a longitudinal costal strip; (c, d) High magnification of anterior transverse costal strips.

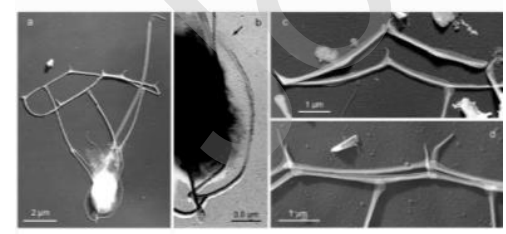


Fig. 9.a-j. Stephanacantha formosa TEM (i, j) and LM (a-h; phase contrast) whole mounts from West Australia (a-c), the Caribbean Sea (d), and the equatorial Pacific Ocean (e-j). (a-h) Selected specimens to show the morphological variability encountered; (i) Detail (from j; reversed printing) of anterior transverse and longitudinal costal strips. (j) Complete cell; notice the highly irregular joints between anterior transverse (12) and longitudinal costal strips (4). The scale bar (a) applies to all light micrographs.

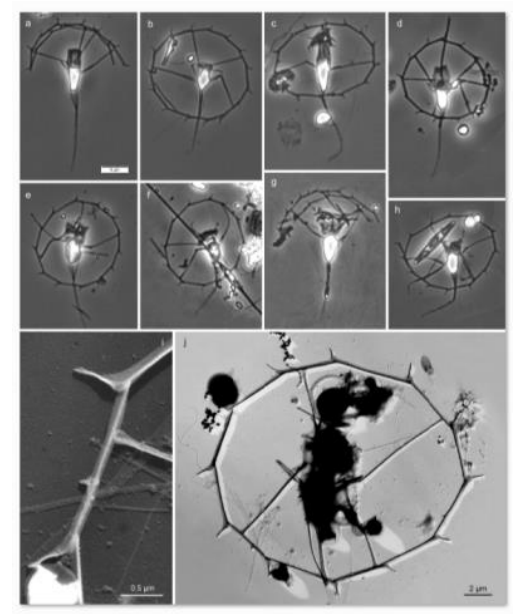

Fig. 10.a-q. Stephanacantha zigzag TEM $(a, f, j)$ and LM whole mounts (b-e, g-i; phase contrast), and Syndetophyllum pulchellum TEM ( $k, q)$ and LM (I-p; phase contrast) whole mounts from the Gulf of California, Mexico (a, b, I-n, q), West Australia (c, d, o, p), the equatorial Pacific Ocean (e, j), the Andaman Sea, Thailand ( $f, k)$, the Sargasso Sea $(g, h)$, and the Caribbean Sea (i). $(\mathbf{a}, \mathbf{f}, \mathbf{j})$ Complete cells ( $a$; inverted printing) from different regions showing complete agreement in size and morphological particulars; (b-e, g-i) Selected specimens to show the variability encountered across all regions sampled; the species diagnostic features are clearly displayed; $(\mathbf{k}, \mathbf{q})$ Complete cells displaying details of lorica construction and costal strip elaboration; (I-p) Selected specimens from across the regions sampled; notice that this species can be reliably identified from LM. The scale bar (g) applies to all light micrographs. 


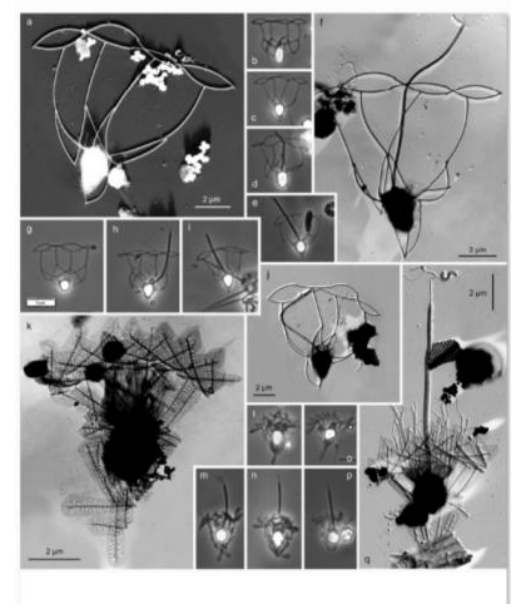


Table 1. Dimensional characteristics of lorica and flagellum. Average value, standard deviation, overall range and sample size are included for each parameter measured.

\begin{tabular}{|c|c|c|c|c|}
\hline & $\begin{array}{c}\text { Lorica height (incl. } \\
\text { nonmineralized stalk) }\end{array}$ & $\begin{array}{c}\text { Non-mineralized } \\
\text { stalk }\end{array}$ & $\begin{array}{c}\text { Diam. anterior } \\
\text { transverse costa }\end{array}$ & Flagellum \\
\hline Calotheca alata & $\begin{array}{c}11.9 \pm 0.87 \\
9.7-13.0 / n=14\end{array}$ & & $\begin{array}{c}7.9 \pm 0.63 \\
6.5-8.8 / n=14\end{array}$ & $\begin{array}{c}14.6 \pm 2.82 \\
11.6-18.6 / n=7\end{array}$ \\
\hline $\begin{array}{l}\text { Stephanacantha } \\
\text { campaniformis }\end{array}$ & $\begin{array}{c}11.0 \pm 0.64 \\
9.8-13.0 / n=28\end{array}$ & & $\begin{array}{c}7.0 \pm 0.58 \\
5.3-9.0 / n=28\end{array}$ & $\begin{array}{c}12.3 \pm 2.54 \\
8.9-14.9 / n=4\end{array}$ \\
\hline $\begin{array}{l}\text { Stephanacantha } \\
\text { dichotoma }\end{array}$ & $\begin{array}{c}17.0 \pm 2.07 \\
14.5-22.2 / n=25\end{array}$ & $\begin{array}{c}3.7 \pm 0.91 \\
2.3-5.6 / n=25\end{array}$ & $\begin{array}{c}7.5 \pm 0.71 \\
6.3-9.1 / n=25\end{array}$ & $\begin{array}{c}10.2 \pm 1.53 \\
7.9-14.6 / n=17\end{array}$ \\
\hline $\begin{array}{l}\text { Stephanacantha } \\
\text { dichotoma } \\
\text { (Ic>3) }\end{array}$ & $\begin{array}{c}23.7 \pm 1.33 \\
22.1-26.0 / n=8\end{array}$ & $\begin{array}{c}6.5 \pm 1.64 \\
4.5-9.5 / n=8\end{array}$ & $\begin{array}{c}9.1 \pm 0.58 \\
8.5-10.1 / n=8\end{array}$ & \\
\hline $\begin{array}{l}\text { Stephanacantha } \\
\text { formosa }\end{array}$ & $\begin{array}{c}26.3 \pm 1.74 \\
23.9-29.3 / n=6\end{array}$ & $\begin{array}{c}9.6 \pm 1.81 \\
7.0-13.0 / n=20\end{array}$ & $\begin{array}{c}17.2 \pm 0.96 \\
15.7-19.2 / n=24\end{array}$ & $\begin{array}{c}16.8 \pm 2.51 \\
14.4-19.5 / n=4\end{array}$ \\
\hline $\begin{array}{l}\text { Stephanacantha } \\
\text { oceanica }\end{array}$ & $\begin{array}{c}9.2 \pm 0.36 \\
8.8-9.7 / n=6\end{array}$ & & $\begin{array}{c}5.9 \pm 0.23 \\
5.6-6.3 / n=6\end{array}$ & $\begin{array}{c}8.9 \pm 1.26 \\
7.8-10.7 / n=4\end{array}$ \\
\hline $\begin{array}{l}\text { Stephanacantha } \\
\text { parvula }\end{array}$ & $\begin{array}{c}9.6 \pm 0.72 \\
8.3-11.3 / n=59\end{array}$ & & $\begin{array}{c}6.6 \pm 0.53 \\
5.6-7.9 / n=59\end{array}$ & $\begin{array}{c}11.6 \pm 3.47 \\
4.0-25.0 / n=43\end{array}$ \\
\hline $\begin{array}{l}\text { Stephanacantha } \\
\text { zigzag }\end{array}$ & $\begin{array}{c}9.7 \pm 0.78 \\
8.4-11.4 / n=29\end{array}$ & & $\begin{array}{c}7.9 \pm 0.58 \\
7.1-9.3 / n=29\end{array}$ & $\begin{array}{c}10.6 \pm 2.23 \\
6.4-14.1 / n=12\end{array}$ \\
\hline $\begin{array}{l}\text { Syndetophyllum } \\
\text { pulchellum }\end{array}$ & $\begin{array}{c}7.0 \pm 0.55 \\
6.1-7.7 / n=13\end{array}$ & & $\begin{array}{c}5.5 \pm 0.70 \\
4.4-7.0 / n=13\end{array}$ & $\begin{array}{c}11.0 \pm 1.90 \\
7.5-13.6 / n=7\end{array}$ \\
\hline
\end{tabular}


Table 2. Occurrence pattern of species discussed here.

\begin{tabular}{|c|c|c|c|c|c|c|c|}
\hline & 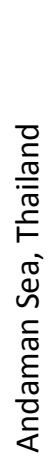 & 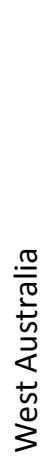 & 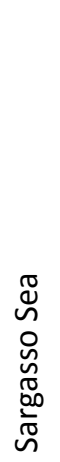 & 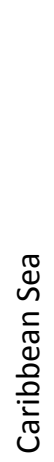 & 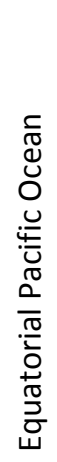 & 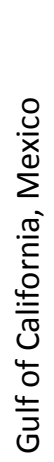 & 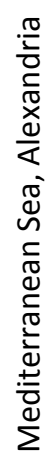 \\
\hline Calotheca alata & $x$ & $x$ & & & & & \\
\hline $\begin{array}{l}\text { Stephanacantha } \\
\text { campaniformis }\end{array}$ & & & & & $x$ & $x$ & \\
\hline S. dichotoma & $\mathrm{x}$ & $x$ & $\mathrm{x}$ & $x$ & $\mathrm{x}$ & $\mathrm{x}$ & $\mathrm{x}$ \\
\hline S. formosa & $\mathrm{x}$ & $x$ & $\mathrm{x}$ & $x$ & $\mathrm{x}$ & $\mathrm{x}$ & $x$ \\
\hline S. oceanica & & $\mathrm{x}$ & $\mathrm{x}$ & & & & \\
\hline S. parvula & $\mathrm{x}$ & $\mathrm{x}$ & $\mathrm{x}$ & $\mathrm{x}$ & $\mathrm{x}$ & & \\
\hline S. zigzag & $x$ & $\mathrm{x}$ & $\mathrm{x}$ & $x$ & $\mathrm{x}$ & $x$ & $x$ \\
\hline $\begin{array}{l}\text { Syndetophyllum } \\
\text { pulchellum }\end{array}$ & $x$ & $x$ & & & $x$ & & $x$ \\
\hline
\end{tabular}

Table 3. Length and number of transverse costal strips in selected individuals of S. formosa.

\begin{tabular}{|c|c|c|c|c|c|c|c|c|}
\hline & Pac_140 $140^{\circ}$ & Pac_ $140^{\circ} \mathrm{W}$ & $\mathrm{Pac} \_4^{\circ} \mathrm{N} / 87^{\circ} \mathrm{W}$ & W. Austr. & W. Austr. & W. Austr. & W. Austr. & W. Austr. \\
\hline Mean & 4.12 & 4.04 & 4.30 & 4.16 & 4.08 & 4.07 & 4.14 & 3.94 \\
\hline SD & 0.73 & 0.53 & 0.69 & 0.49 & 0.66 & 0.49 & 0.53 & 0.55 \\
\hline Min. & 3.21 & 3.16 & 2.95 & 3.44 & 2.76 & 3.44 & 3.23 & 3.05 \\
\hline Max & 5.26 & 4.96 & 5.40 & 5.12 & 5.47 & 5.02 & 4.97 & 5.07 \\
\hline$n$ & 12 & 13 & 12 & 12 & 12 & 15 & 13 & 13 \\
\hline
\end{tabular}

